\title{
EFFECT OF GROWING MEDIA, TYPES OF FERTILIZATION AND THEIR INTERACTIONS ON GROWTH, FLOWERING, BULBS PRODUCTIVITY AND SOME CHEMICAL CONSTITUENTS OF IRIS TINGITANA CV. GOLDEN BEAUTY
}

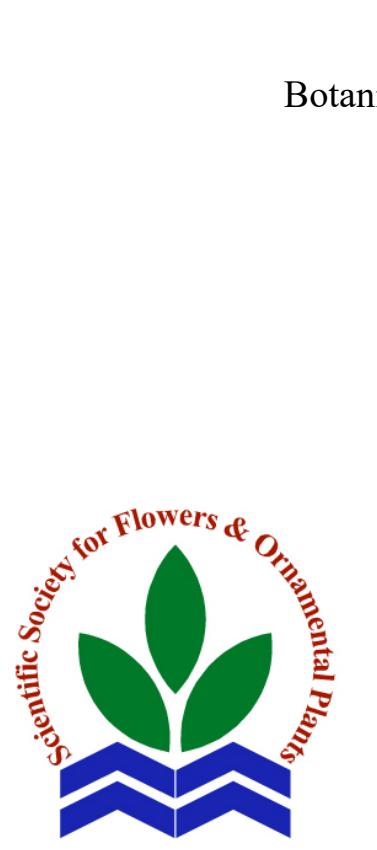

Scientific J. Flowers \& Ornamental Plants, 8(2):251-262 (2021).

Received:

$1 / 1 / 2021$

Accepted:

$3 / 2 / 2021$

Corresponding author: Abla H. Dorgham abladorgham@yahoo.com

Abla H. Dorgham and Hanan M.A. Khedr

\begin{abstract}
The present experiment was conducted at the nursery of Horticulture Research Institute, Agriculture Research Center, Giza, Egypt, throughout two successive seasons (2018/2019, 2019/2020), with the aim to study the individual as well as the combined effects of different growing media [sand, mixture of sand + clay $(1: 1, \mathrm{v} / \mathrm{v})$ and mixture of sand + compost $(1: 1, \mathrm{v} / \mathrm{v})]$ and different types of fertilization treatments (bio and chemical fertilizers) for achieving the hope of producing Iris tingitana $\mathrm{cv}$. Golden Beauty bulbs and flowers of high quality under Egyptian condition. The results emphasized the great influence of sand + clay mixture $(1: 1, \mathrm{v} / \mathrm{v})$ in improving most vegetative growth parameters. Moreover, the earliest bulbs flowering with significant effect were obtained as a result of plants grown in the same mixture. Also, the same mixture gave the largest flower diameter and succeeded to increase flower stem length, flower stem diameter and fresh weight of flower stem. Insignificant effects were observed on either circumference or fresh weight of the replace bulb due to using the different growing media in plantation. Also, the same effect was noticed on No. of bulblets/plot (bulblets yield) and fresh weight of bulblet. Chemical constituents of the new formed bulbs were also affected by the different growing media in which great influence was noticed due to using the mixture of sand + clay. Referring to the effect of the different fertilizer treatments on plant traits, kristalon proved its mastery in improving most plant traits in both seasons comparing with that obtained from amino acid of argenine at either the levels of 50 or $75 \mathrm{ppm}$, which occupied the second rank in improving plant quality in this respect. From the aforementioned results, it could be recommended to plant Iris tingitana cv. Golden Beauty in the mixture of sand + clay $(1: 1, \mathrm{v} / \mathrm{v})$ with treating plants with kristalon at $2 \mathrm{~g} / \mathrm{l}$ and applying amino acid (argenine at $75 \mathrm{ppm}$ ) in some instances.
\end{abstract}

Key words: Iris tingitana cv. Golden Beauty, growing media, amino acid (argenine) and kristalon.

\section{INTRODUCTION}

Irises, Family Iridaceae, are ornamental bulbous and are a group of great economic potential for their commercial importance in cut flowers trade as valued much for beauty and fragrance. Irises are found throughout temperate and subtropical zones of the northern hemisphere, and more than 300 species are known (Hoog, 1980). They reflect the diversity of the color of the rainbow which makes irises desirable cut flowers, even though the vase life is short. Irises have a rootstock that can be rhizomatous, bulbus or corms (De Hertogh and Le Nard, 1993). Irises face many problems under Egyptian conditions such as 
the deterioration of flowers quality year after year ...etc.

Growing media are considered major factors in controlling the physiological pattern as well as the morphological traits of many plants. In this regard, many authors agreed that sandy soil is usually considered the cheapest and most readily available material (Floyed, 1965 and Hall and Richamound, 1968). Soil fertility means the soil capacity to supply the plants with their requirements, water and air along the growth season (Askar, 1998).

The surface charge is important in the exchange of nutrients, so although clay is full of nutrients, it tends to be bound to the particles and is not available to plant roots.

Sandy soil has poor hydrophysical properties, i.e. high rate of evaporation, porosity, lack of the organic matter, less water holding capacity and limited nutrient elements supplying. Researches are interested in improving the physical statues of soil under reclamation in order to solve the problem of the poor soil under Egyptian conditions and obtain satisfactory plant growth. Soil conditioners are widely utilized to compensate the limited supply of nutrients as well as increase water use efficiency. (John and David, 2000).

Referring to the effect of growing media on plant morphological traits, Nabih et al. (1987) on Iris cv. Wedgewood reported that sand medium increased bulb dry weight, but did not affect number of bulbs or bulblets. Nabih (1991) on Freesia refracta cv. Aurora claimed that sand/compost dried leaves and sand/peatmoss media $(1: 1, \mathrm{v} / \mathrm{v})$ had great effects on corms yield. El-Ashry et al. (1995) concluded that clay/composted dried leaves appreciably increased fresh and dry weights of new bulbs of amaryllis (Hippeastrum vittatum, Herb.). Arafa et al. (1996) on Freesia refracta cv. Aurora added that using clay medium was on the account of corms and cormels yield, whereas, composted leaves medium and its mixture with sand $(1: 1, \mathrm{v} / \mathrm{v})$ or sand medium, enriched with chemical fertilization of NPK at $15 \mathrm{~g} /$ plant revealed favorable effects in this concern.

Therefore, the experimental trial was performed to find out the individual and the combined effect of different growing media and different types of fertilization on growth flowering, bulbs productivity and some chemical constituent of the new formed bulbs of Iris tingitana cv. Golden Beauty.

Evidently the problems of inadequate fertilization are extremely complex and that, in general, lack of essential macro or micro elements which reduce growth and ultimately cause death.

The commercial preparation of kristalon (a complete fertilizer with macro and micro elements) proved its superiority for improving quality of various plants as mentioned by many scientists. Undoubtedly, macro and micro elements play a major role in growth and developments of any plant. In this regard many authors focused their studies in improving plant quality. In this respect El-Ashry et al. (1995) on Hippeastrum cv. Apple Blossom and Singh (1996) on gladiolus concluded that using chemical fertilization (kristalon or NPK) improved vegetative growth. Moreover, Khalafalla et al. (2000) on Ornithogalum thyrsoides reported that using the medium and high rates of NPK ( 3 and $4 \mathrm{~g} /$ pot) significantly increased number of spikes/pot and florets/spike, spike stem diameter and fresh and dry weights of cut spike. ElHanafy et al. (2005) on Freesia refracta cv. Aurora mentioned that using the commercial product of multi feed (13: 13: 13) caused an increment in spike stem diameter and length of the main spike. Meanwhile, using the mixture of $\mathrm{N}, \mathrm{P}$ and $\mathrm{K}$ delayed to some extent flowering date. Also, all chemical fertilization treatments increased fresh weight of cut spike. Mansour et al. (2015) on Gladiolus grandiflorus cv. Peter Pears stated that using the low kristalon level (2 g/l) gave the tallest plants and the highest number of leaves/plant. 
Amino acids have traditionally been considered as precursors and constituents of proteins, many amino acids also act as precursors of other nitrogen containing compounds, e.g. nucleic acids. Not long ago, many experiments implied that amino acid can play wide roles in plants including as regulatory and signaling molecules (Rai, 2002).

Many authors studied the effect of amino acids (as biostimulators) on growth, chemical composition, yield and its quality of plants. In this regard, Shehata et al. (2011) concluded that spraying celeriac plants with amino acids at 400 and $750 \mathrm{ppm}$ revealed that the higher rate $(750 \mathrm{ppm})$ significantly increased plant height and fresh and dry weights of green yield (leaves) when the higher rate $750 \mathrm{ppm}$ was sprayed on the plants. Moreover, the same rate $(750 \mathrm{ppm})$ significantly increased total sugar content.

Also, amino acids are well know biostimulants which have positive effects on plant growth and yield and significantly mitigate the damage caused by abiotic stresses. In this respect, Sadak et al. (2015) studied the effect of exogenously treatment of amino acids on faba been Giza 843 plants growing under seawater stress, with the aim to mitigate the reduction of salinity damage by using a mixture of amino acids with different concentrations $(0,500,1000$ or $1500 \mathrm{mg} / \mathrm{l})$ to improve morphological parameters and thus raising the level of plant yield. Results indicated that the reductions in shoot length, number of leaves/plant, fresh and dry weight of shoots, total carbohydrates caused by the irrigation of saline water (3.13 and $6.25 \mathrm{ds} / \mathrm{m}$ ), amino acids application as foliar spray significantly improved all the reduced parameters due to seawater stress. In confirmation, the highest level of amin acids of $1500 \mathrm{mg} / \mathrm{l}$ exerted the strongest effect in alleviating the harmful effect of seawater salinity stress.

Therefore, the present experiment was performed to find out the effect of the individual as well as the combined effects of different growing media and different types of fertilization treatments for achieving the hope of improving plant quality of Iris tingitana cv. Golden Beauty under local Egyptian conditions.

\section{MATERIALS AND METHODS}

The pot experimental study was carried out at the nursery of Horticulture Research Institute, Agriculture Research Center, Giza, Egypt throughout the two successive growing seasons of 2018/2019 and $2019 / 2020$ to study the individual as well as the combined effects of different growing media and types of fertilization treatments (chemical and biofertilizers) for achieving the hope of producing Iris tingitana bulbs and flowers of high quality under the condition of Egypt. The Iris tingitana cv. Golden Beauty bulbs with an average weight of $10 \mathrm{~g}$ and had 8-9 $\mathrm{cm}$ circumference were chosen for the present investigation. The bulbs (one bulb/pot) were cultivated and vertically laid in plastic pots of $25 \mathrm{~cm}$ diameter packed with the three chosen growing media, mention later, in a full sunny place on $15^{\text {th }}$ Nov, in the first and second seasons.

Two factors were involved in the present study, the first was potting media, the second was fertilization type. The three different potting media chosen; the first consisted of sand (GM1) while the second one (GM2) consisted of sand + clay $(1: 1 \mathrm{v} / \mathrm{v})$. The third growing medium (GM3) contained sand + composted leaves $(1: 1 \mathrm{v} / \mathrm{v})$, chemical analysis of growing media is shown in Table (a). Iris plants received the different fertilization treatments commencing from January $13^{\text {th }}$ in every season and then at 15 days intervals. The plants received fertilization treatments 5 times throughout the growth seasons. Two levels of amino acid arginine (50 and $75 \mathrm{ppm}$ ) and the water soluble chemical fertilizer NPK (Kristalon 19:19:19) was used at the level $2 \mathrm{~g} / 1$ and control treatment (without any fertilizer). In this respect, 12 treatments were carried out in the two experimental seasons ( 3 growing media $\times 4$ fertilization treatments). 
Abla H. Dorgham and Hanan M.A. Khedr

Table a. Chemical analysis of growing media according at Soil and Water Research Institute, Horticulture Research Institute, Agriculture Research Center.

\begin{tabular}{lcccccccccc}
\hline \multirow{2}{*}{ Growing media } & \multirow{2}{*}{$\mathbf{p H}$} & $\mathbf{E C}$ & \multirow{2}{*}{$\mathbf{S P}$} & \multicolumn{3}{c}{ Anions (meq/l) } & \multicolumn{3}{c}{ Cations (meq/l) } \\
& & $\mathbf{d S / m})$ & & $\mathbf{H C O}_{3}^{-}$ & $\mathbf{C l}^{-}$ & $\mathbf{S O} \mathbf{4}^{-}$ & $\mathbf{C a}^{++}$ & $\mathbf{M g}^{++}$ & $\mathbf{N a}^{+}$ & $\mathbf{K}^{+}$ \\
\hline Sand & 6.73 & 4.75 & 25.00 & 0.90 & 58.99 & 52.28 & 11.11 & 6.05 & 58.20 & 10.34 \\
Sand/clay & 7.50 & 4.41 & 45.30 & 3.50 & 27.30 & 51.60 & 28.00 & 12.10 & 34.30 & 7.90 \\
Sand/compost & 7.65 & 3.70 & 38.30 & 9.90 & 20.90 & 27.80 & 16.00 & 8.60 & 19.90 & 14.10 \\
\hline
\end{tabular}

The experimental layout was designed to provide randomized complete design in factorial type containing three replicates. Each replicate contained twelve treatments (3) growing media $\times 4$ fertilization treatments). Three plants were used as a plot for each treatment.

The data recorded for the vegetative growth parameters included; plant height (cm), No. of leaves/plant, fresh weight of the leaves (g). While the flowering data included; number of days to flowering, flower diameter $(\mathrm{cm})$, flower stem length $(\mathrm{cm})$, flower stem diameter $(\mathrm{cm})$, fresh weight of cut flower ( $\mathrm{g}$ ) and fresh weight of flower stem $(\mathrm{g})$. In addition, the circumference of the new bulb $(\mathrm{cm})$, fresh weight of the new bulb (g), No. of bulblets/plot (bulbs yield), fresh weight of bulblet (g) were obtained.

The data recorded for the chemical composition included; carbohydrates nitrogen, phosphorus and potassium $\%$ in the new bulbs. Nitrogen was determined by micro-Kjeldahle apparatus (Black, 1965), phosphorus was colorimetrically determined in the acid digested using ascorbic acid methods (John, 1970). Potassium was determined using the flamephotometer (Dewis and Freitas, 1970). Besides, total carbohydrates content in the new bulbs was determined using colorimetric methods described by Smith et al. (1956).

Data were then tabulated and statistically analyzed using SAS program (1994) and means were compared by L.S.D. method according to Snedecor and Cochran (1980).

\section{RESULTS AND DISCUSSION}

\section{Vegetative growth:}

\section{Vegetative growth height (plant height):}

Clear differences were observed on plant height due to using the different growing media in plantation in both seasons. In this connection, the mixture of sand + clay proved its mastery in producing the highest values in the two seasons, followed in the second rank by the effect of sand medium. In contrast, the least scores were gained due to using the mixture of sand + compost in both seasons.

Concerning the effect of the different types of fertilization treatments on the same parameter, it is obvious from data presented in Table (1) that kristalon treatment was the best in elevating plant height in the two seasons, and occupied the first category in increasing such trait.

In the matter of the interactions, it is evident from tabulated data the great influence of growing the plants in sand medium with receiving plants kristalon at 2 $\mathrm{g} / \mathrm{l}$, followed in the second position by those grown in the mixture of sand + clay and treated with arginine at $75 \mathrm{ppm}$ in both seasons. On the contrary, the least scores were obtained as a result of growing plants in sand medium and untreated with fertilization in the two seasons.

\section{No. of leaves/plant:}

Insignificant effects on number of leaves/plant were observed as influenced by the different types of growing media used, and the different fertilization treatments as well as the interaction between both as indicated in Table (1). 
Table 1. Effect of different growing media, fertilization treatments and their interaction on vegetative growth of Iris tingitana $\mathrm{cv}$. Golden Beauty in the two seasons of 2018/2019 and 2019/2020.

\begin{tabular}{|c|c|c|c|c|c|c|c|c|}
\hline \multirow{3}{*}{ Treatments (B) } & \multicolumn{8}{|c|}{ Growing media (A) } \\
\hline & Sand & $\begin{array}{c}\text { Sand }+ \\
\text { clay }\end{array}$ & $\begin{array}{c}\text { Sand }+ \\
\text { compost }\end{array}$ & Mean (B) & Sand & $\begin{array}{c}\text { Sand }+ \\
\text { clay }\end{array}$ & $\begin{array}{c}\text { Sand }+ \\
\text { compost }\end{array}$ & Mean (B) \\
\hline & \multicolumn{4}{|c|}{ 2018/2019 } & \multicolumn{4}{|c|}{$2019 / 2020$} \\
\hline & \multicolumn{8}{|c|}{ Plant height (cm) } \\
\hline Control & 24.75 & 29.38 & 31.00 & 28.38 & 27.43 & 32.14 & 35.00 & 31.52 \\
\hline Arginine (50 ppm) & 36.00 & 40.00 & 36.25 & 37.42 & 39.20 & 42.71 & 40.11 & 40.67 \\
\hline Arginine (75 ppm) & 38.87 & 45.88 & 30.50 & 38.42 & 40.65 & 49.38 & 34.28 & 41.43 \\
\hline Kristalon (2 g/l) & 48.63 & 42.25 & 30.45 & 40.44 & 49.69 & 44.55 & 33.63 & 42.62 \\
\hline Mean (A) & 37.06 & 39.38 & 32.05 & & 39.24 & 42.19 & 35.75 & \\
\hline \multirow[t]{2}{*}{ L.S.D $(0.05)$} & \multicolumn{4}{|c|}{$\mathrm{A}=5.823 \mathrm{~B}=7.225 \mathrm{~A} \times \mathrm{B}=11.523$} & \multicolumn{4}{|c|}{$\mathrm{A}=7.441 \mathrm{~B}=9.573 \mathrm{~A} \times \mathrm{B}=12.245$} \\
\hline & \multicolumn{8}{|c|}{ No. of leaves/plant } \\
\hline Control & 7.56 & 8.00 & 7.75 & 7.76 & 8.35 & 8.85 & 9.45 & 8.88 \\
\hline Arginine (50 ppm) & 8.75 & 8.75 & 8.75 & 8.75 & 9.95 & 9.95 & 9.85 & 9.92 \\
\hline Arginine (75 ppm) & 9.00 & 8.55 & 8.75 & 8.77 & 10.25 & 9.65 & 9.65 & 9.85 \\
\hline Kristalon (2 g/l) & 9.00 & 9.03 & 8.25 & 8.76 & 10.80 & 11.05 & 9.20 & 10.35 \\
\hline Mean (A) & 8.58 & 8.60 & 8.37 & & 9.84 & 9.88 & 9.53 & \\
\hline \multirow[t]{2}{*}{$\underline{L . S . D}_{(0.05)}$} & \multicolumn{4}{|c|}{$\mathrm{A}=\mathrm{N} . \mathrm{S} \mathrm{B}=\mathrm{N} . \mathrm{S} \mathrm{A} \times \mathrm{B}=\mathrm{N} . \mathrm{S}$} & \multicolumn{4}{|c|}{$A=N . S B=N . S A \times B=N . S$} \\
\hline & \multicolumn{8}{|c|}{ Fresh weight of the leaves (g) } \\
\hline Control & 1.63 & 2.67 & 3.95 & 2.75 & 2.47 & 3.41 & 4.90 & 3.59 \\
\hline Arginine (50 ppm) & 4.69 & 5.05 & 4.48 & 4.74 & 5.37 & 6.20 & 5.70 & 5.76 \\
\hline Arginine (75 ppm) & 5.50 & 5.89 & 4.03 & 5.14 & 6.52 & 6.78 & 4.89 & 6.06 \\
\hline Kristalon (2 g/l) & 5.43 & 7.32 & 3.50 & 5.41 & 6.42 & 8.30 & 4.50 & 6.41 \\
\hline Mean (A) & 4.31 & 5.23 & 3.98 & & 5.20 & 6.17 & 5.00 & \\
\hline L.S.D $(0.05)$ & \multicolumn{4}{|c|}{$\mathrm{A}=1.051 \mathrm{~B}=1.353 \mathrm{~A} \times \mathrm{B}=2.103$} & \multicolumn{4}{|c|}{$\mathrm{A}=0.904 \mathrm{~B}=1.163 \mathrm{~A} \times \mathrm{B}=1.807$} \\
\hline
\end{tabular}

L.S.D $(0.05)=$ Least significant differences at 0.05 level of probability.

\section{Fresh weight of the leaves:}

Evidently, data outlined in Table (1) show the prevalence of growing plants in the mixture of sand+ clay in increasing fresh weight of leaves in both seasons, followed in the second degree for plants grown in sand medium. In contrast, the least scores were obtained due to using the mixture of sand+ compost in plantation. Meanwhile, adding kristalon as a fertilizer treatment was the best in producing the heaviest fresh weight and occupied the first rank in this regard, followed in the second degree by plants treated with arginine at $75 \mathrm{ppm}$, whereas, the least values were obtained by untreated control plants in the two seasons. Concerning the interaction, the highest records of fresh weight of leaves in the two seasons were a result of plants grown in the mixture of sand + clay and received kristalon in the two seasons.

The prevalence effect of amino acids and kristalon (NPK) as fertilization presented in the current study, revealed great influence on vegetative growth parameter, which was also noiced by other authors on other plants. Auda (1992) and El-Ashry et al. (1995) on Amaryllis, Amarject et al. (1995) and ElBably (1998) on Polianthus tuberosa, Mahdy (1995) on Iris and Khalafalla et al. (2000) on Ornithogalum thyrsoides and Shehata et al. (2011) on celerias. Also, the increase in plant height as a result of chemical fertilization (kristalon) is similar to that recorded by Khalafalla et al. (2000) on Ornithogalum thyrsoides, Soliman (2000) on Iris tingitana cv. Purple Sensation. Agina et al. (2005) on Bougainvillea glabra, 
Cordyline terminalis, Ficus microcarpanitida Hawaii and Jasminum sambac and Mansour et al. (2015) on Gladiolus grandiflorus cv. Peter pears.

\section{Flowering characteristics:}

\section{Number of days from planting to flowering:}

The earliest bulbs flowering with significant effect was obtained as a result of plants grown in the mixture of sand + clay, followed by those which grown in sand medium, whereas, the mixture of sand+ compost tended to delay flowering than that gained from other treatments used. Meanwhile, receiving plants arginine at either 50 or $75 \mathrm{ppm}$ significantly recorded the earliest bulbs flowering in the two seasons. On the other side, the interactions indicated the superiority of treating plants which grown in the mixture of sand + clay with arginine at $50 \mathrm{ppm}$ in producing the earliest bulbs flowering in both seasons (Table, 2).

\section{Flower diameter:}

Data presented in Table (2) reveal the superiority of the mixture of sand + clay in producing the largest flower diameter in the two seasons. In contrast, sand medium recorded the lowest value in both seasons. Meanwhile, supplying plants with kristalon ( $2 \mathrm{~g} / \mathrm{l})$ was the best fertilizer treatment in giving the largest flower diameter, whereas, untreated control plants recorded the least scores in both seasons. The interaction, on the other side, indicated the prevalence of supplying plants grown in sand/clay medium either with arginine at $75 \mathrm{ppm}$ of kristalon (2 $\mathrm{g} / \mathrm{l}$ ) in giving the largest flower diameter in the two seasons.

\section{Flower stem length:}

Clear influence with significant effect on flower stem length was noticed in both seasons due to growing plants in sand/clay medium as it gave rise to the utmost highest values in the two seasons (Table, 2). On the other side, all fertilization treatments caused an increment in flower stem length comparing with that gained from untreated control plants, but the effect did not reach to the level of significance. On the other side, and referring to the effects of the interactions, the results indicated the prevalence of growing plants in the mixture of sand/clay mixture and supplying plant with either arginine at $75 \mathrm{ppm}$ or kristalon at $1 \mathrm{~g} / \mathrm{l}$ in increasing flower stem length in both seasons.

\section{Flower stem diameter:}

Evidently, data scored in Table (2) exert the beneficial effect of growing plant in the mixture of sand + clay in both seasons, in elevating flower stem diameter, followed in the second rank with plants grown in the mixture of sand + compost in the two seasons. In contrast, the least scores were obtained due to planting the bulbs in sand medium in both seasons. On the other side, receiving plants kristalon treatment gave rise to the utmost highest values followed in the second degree by those treated with either arginine at 50 or at $75 \mathrm{ppm}$ in increasing flower stem diameter compared with the control in both seasons. The interaction, on the other side, proved the superiority of receiving plants grown in the mixture of sand/clay and supplied with either argenine at $75 \mathrm{ppm}$ or kristalon at $2 \mathrm{~g} / 1$ in the two seasons.

\section{Fresh weight of cut flowers:}

Data exhibited in Table (2) exert the prevalence of growing plants in the mixture of sand + clay in raising fresh weight of cut flower, compared with that attained from the other growing media used in both seasons. Also, considerable increment in fresh weight of cut flower was observed comparing with control due to receiving plants the different fertilization treatments in the two seasons. Meanwhile, the interaction indicated the superiority of supplying plants grown in the mixture of sand + clay with kristalon treatment in raising fresh weight of cut flower in both seasons. 
Table 2. Effect of different growing media, fertilization treatments and their interaction on flowering characteristics of Iris tingitana cv. Golden Beauty in the two seasons of 2018/2019 and 2019/2020.

\begin{tabular}{|c|c|c|c|c|c|c|c|c|}
\hline \multirow{3}{*}{ Treatments $(B)$} & \multicolumn{8}{|c|}{ Growing media (A) } \\
\hline & Sand & $\begin{array}{l}\text { Sand + } \\
\text { clay }\end{array}$ & $\begin{array}{c}\text { Sand + } \\
\text { compost }\end{array}$ & Mean (B) & Sand & $\begin{array}{c}\text { Sand + } \\
\text { clay }\end{array}$ & $\begin{array}{c}\text { Sand + } \\
\text { compost }\end{array}$ & Mean (B) \\
\hline & \multicolumn{4}{|c|}{$2018 / 2019$} & \multicolumn{4}{|c|}{$019 / 2020$} \\
\hline & \multicolumn{8}{|c|}{ Number of days from planting to flowering (days) } \\
\hline Control & 118.25 & 114.25 & 111.00 & 114.50 & 112.13 & 117.22 & 115.50 & 117.95 \\
\hline Arginine (50 ppm) & 103.75 & 100.50 & 114.50 & 106.25 & 106.78 & 103.15 & 117.62 & 109.18 \\
\hline Arginine (75 ppm) & 99.75 & 104.50 & 110.25 & 104.83 & 102.71 & 107.87 & 112.87 & 107.82 \\
\hline Kristalon (2 g/l) & 112.50 & 107.75 & 113.25 & 111.17 & 115.54 & 112.50 & 116.61 & 114.88 \\
\hline Mean (A) & 108.56 & 106.75 & 112.25 & & 111.54 & 110.18 & 115.65 & \\
\hline \multirow[t]{2}{*}{ L.S.D (0.05) } & \multicolumn{4}{|c|}{$\mathrm{A}=2.560 \mathrm{~B}=3.293 \mathrm{~A} \times \mathrm{B}=5.119$} & \multicolumn{4}{|c|}{$\mathrm{A}=2.393 \mathrm{~B}=3.078 \mathrm{~A} \times \mathrm{B}=4.785$} \\
\hline & \multicolumn{8}{|c|}{ Flower diameter $(\mathrm{cm})$} \\
\hline Control & 10.00 & 1.87 & 12.25 & 1.38 & 10.76 & 2.69 & 13.35 & 2.27 \\
\hline Arginine (50 ppm) & 12.25 & 13.68 & 13.53 & 3.15 & 13.54 & 4.46 & 14.29 & 4.09 \\
\hline Arginine (75 ppm) & 12.63 & 4.63 & 12.38 & 3.21 & 14.09 & 5.47 & 13.16 & 4.24 \\
\hline Kristalon (2 g/l) & 13.23 & 14.45 & 13.13 & 3.60 & 14.51 & 5.25 & 13.92 & 4.56 \\
\hline Mean (A) & 12.03 & 13.66 & 12.82 & & 13.22 & 4.47 & 13.68 & \\
\hline \multirow[t]{2}{*}{ L.S.D $(0.05)$} & \multicolumn{4}{|c|}{$\mathrm{A}=0.680 \mathrm{~B}=1.052 \mathrm{~A} \times \mathrm{B}=1.760$} & \multicolumn{4}{|c|}{$\mathrm{A}=0.880 \mathrm{~B}=1.132 \mathrm{~A} \times \mathrm{B}=1.962$} \\
\hline & \multicolumn{8}{|c|}{ Flower stem length (cm) } \\
\hline Control & 26.00 & 9.88 & 36.50 & 0.79 & 27.32 & 1.46 & 38.80 & 2.53 \\
\hline Arginine (50 ppm) & 31.50 & 38.00 & 34.25 & 4.58 & 33.49 & 0.03 & 36.13 & 6.54 \\
\hline Arginine (75 ppm) & 32.69 & 3.00 & 28.50 & 4.73 & 34.27 & 5.36 & 30.71 & 6.78 \\
\hline Kristalon (2 g/l) & 33.75 & 42.25 & 27.75 & 4.58 & 36.03 & 4.25 & 29.75 & 6.67 \\
\hline Mean (A) & 30.98 & 38.28 & 31.75 & & 32.78 & 0.27 & 33.85 & \\
\hline \multirow[t]{2}{*}{ L.S.D (0.05) } & \multicolumn{4}{|c|}{$\mathrm{A}=6.891 \mathrm{~B}=8.865 \mathrm{~A} \times \mathrm{B}=12.543$} & \multicolumn{4}{|c|}{$\mathrm{A}=6.761 \mathrm{~B}=8.697 \mathrm{~A} \times \mathrm{B}=12.361$} \\
\hline & \multicolumn{8}{|c|}{ Flower stem diameter $(\mathrm{cm})$} \\
\hline Control & 2.80 & 3.05 & 4.10 & 3.32 & 3.25 & 3.72 & 4.91 & 3.96 \\
\hline Arginine (50 ppm) & 3.85 & 5.17 & 5.08 & 4.70 & 4.63 & 5.85 & 5.77 & 5.41 \\
\hline Arginine (75 ppm) & 4.34 & 5.42 & 3.95 & 4.57 & 5.06 & 6.12 & 4.64 & 5.27 \\
\hline Kristalon (2 g/l) & 4.90 & 5.52 & 5.07 & 5.16 & 5.50 & 6.14 & 5.76 & 5.79 \\
\hline Mean (A) & 3.97 & 4.79 & 4.55 & & 4.61 & 5.46 & 5.27 & \\
\hline \multirow[t]{2}{*}{ L.S.D (0.05) } & \multicolumn{4}{|c|}{$\mathrm{A}=0.361 \mathrm{~B}=0.751 \mathrm{~A} \times \mathrm{B}=0.938$} & \multicolumn{4}{|c|}{$\mathrm{A}=0.421 \mathrm{~B}=0.542 \mathrm{~A} \times \mathrm{B}=0.842$} \\
\hline & \multicolumn{8}{|c|}{ Fresh weight of cut flowers (g) } \\
\hline Control & 1.45 & 2.41 & 4.09 & 2.65 & 2.67 & 3.36 & 5.04 & 3.69 \\
\hline Arginine (50 ppm) & 5.24 & 6.09 & 4.76 & 5.36 & 5.97 & 7.06 & 5.73 & 6.25 \\
\hline Arginine (75 ppm) & 5.31 & 6.93 & 3.63 & 5.29 & 6.45 & 7.89 & 4.63 & 6.32 \\
\hline Kristalon (2 g/l) & 4.97 & 7.65 & 5.23 & 5.94 & 5.86 & 8.58 & 6.25 & 6.89 \\
\hline Mean (A) & 4.24 & 5.77 & 4.43 & & 5.24 & 6.72 & 5.41 & \\
\hline \multirow[t]{2}{*}{ L.S.D (0.05) } & $A=$ & $974 \mathrm{~B}=1$. & $53 \mathrm{~A} \times \mathrm{B}=2$ & 2.188 & $A=$ & $392 \mathrm{~B}=1$. & $64 \mathrm{~A} \times \mathrm{B}=$ & 1.964 \\
\hline & & & Fresl & h weight o & lower ste & (g) & & \\
\hline Control & 1.75 & 3.39 & 4.10 & 3.08 & 2.17 & 4.33 & 4.95 & 3.82 \\
\hline Arginine (50 ppm) & 5.45 & 7.19 & 5.16 & 5.94 & 6.38 & 8.32 & 5.98 & 6.89 \\
\hline Arginine (75 ppm) & 6.17 & 6.38 & 3.87 & 5.47 & 7.04 & 7.07 & 4.46 & 6.19 \\
\hline Kristalon (2 g/l) & 4.54 & 9.02 & 5.22 & 6.26 & 5.35 & 9.66 & 6.04 & 7.02 \\
\hline Mean (A) & 4.48 & 6.49 & 4.59 & & 5.24 & 7.34 & 5.35 & \\
\hline$\underline{L . S . D}_{(0.05)}$ & $A=$ & $527 \mathrm{~B}=0$ & $78 \mathrm{~A} \times \mathrm{B}=1$ & 1.174 & $A=$ & $74 \mathrm{~B}=0$ & $11 \mathrm{~A} \times \mathrm{B}=$ & 0.949 \\
\hline
\end{tabular}

L.S.D $D_{(0.05)}=$ Least significant differences at 0.05 level of probability. 


\section{Fresh weight of flower stem:}

The significantly heaviest fresh weight of flower stem belonged to plants grown in the mixture of sand + clay in the two seasons, whereas, the least scores were gained due to using either sand or the mixture of sand + compost. On the other side, the different fertilization treatments proved the superiority of applying kristalon treatments as it gave the highest scores comparing with those recorded from the other fertilization treatments or untreated control in the two seasons. The interaction revealed the prevalence of supplying plants grown in the mixture of sand + clay with kristalon treatment in both seasons (Table, 2).

In this regard, many authors indicated the great effect of amino acid arginine in improving plant morphological traits as mentioned by Emam et al. (2017) on moringa seedling as reported that using arginine at $50 \mathrm{ppm}$ expanded plant height, dry weight of stem and roots and total carbohydrates content in the leaves.

\section{Bulbs productivity:}

\section{Circumference and fresh weight of the} mother bulb:

Insignificant effects on either circumference or fresh weight of the new bulbs were noticed due to using the different growing media and fertilization treatments in the two seasons as indicated in Table (3).

\section{Effect on No. of bulblets/pot (bulblets yield) and fresh weight of bulblet:}

Insignificant effects on No. of bulblets/pot (bulblets yield) and fresh weight of bulblet were noticed in the two seasons, due to using the different growing media and fertilization treatments as indicated in Table (3).

\section{Chemical constituents:}

\section{Total carbohydrates \% in bulbs:}

The mixture of sand + clay was the best growing medium used in raising total carbohydrates $\%$ in bulbs comparing with those obtained from the other growing media in both seasons. Meanwhile, using chemical fertilization of kristalon caused an increment in total carbohydrates \% in bulbs comparing with those recorded from the other fertilization treatments used in two seasons (Table, 4).

On the other hand, and referring to the interaction the highest total carbohydrates \% was obtained as a result of the interaction, between sand/clay medium and kristalon treatment in the two seasons.

\section{Mineral elements:}

\section{a. Nitrogen $\%$ in new formed bulbs:}

Data outlined in Table (4) reveal the mastery of growing plants in sand + compost mixture $(1: 1, \mathrm{v} / \mathrm{v})$ in raising nitrogen $\%$ in the newly formed bulbs in both seasons. Referring to the effect of fertilizer treatments, it is clear from data that applying arginine at $75 \mathrm{ppm}$ was the best treatment in elevating the scored values and occupied the first rank in this respect in both seasons. In the matter of interaction, it is clear from data the prevalence of plants grown in sand + clay mixture $(1: 1, \mathrm{v} / \mathrm{v})$ and treated with arginine at $75 \mathrm{ppm}$ in raising nitrogen \% in the new bulbs in the two seasons.

\section{b. Phosphorus \% in the new formed bulbs:}

The mixture of sand + clay proved its superiority in raising phosphorus \% used in the new formed bulbs comparing with that gained from the other growing media in both seasons. On the other side, the amino acid arginine at $75 \mathrm{ppm}$ proved its mastery in raising phosphorus \% in the new formed bulbs. The interaction, revealed that plants grown in the mixture of sand + clay and treated with kristalon $(2 \mathrm{~g} / \mathrm{l})$ gave the highest value of phosphorus $\%$ in the formed bulbs in the two seasons (Table, 4).

\section{c. Potassium \% in the new formed bulbs:}

Data outlined in Table (4) clear the great influence of growing the bulbs in sand + compost medium in raising potassium $\%$ in 
Table 3. Effect of different growing media, fertilization treatments and their interaction on bulbs productivity of Iris tingitana cv. Golden Beauty in the two seasons of 2018/2019 and 2019/2020.

\begin{tabular}{|c|c|c|c|c|c|c|c|c|}
\hline \multirow{3}{*}{ Treatments (B) } & \multicolumn{8}{|c|}{ Growing media (A) } \\
\hline & Sand & $\begin{array}{c}\text { Sand + } \\
\text { clay }\end{array}$ & $\begin{array}{l}\text { Sand + } \\
\text { compost }\end{array}$ & Mean (B) & Sand & $\begin{array}{c}\text { Sand }+ \\
\text { clay }\end{array}$ & $\begin{array}{c}\text { Sand + } \\
\text { compost }\end{array}$ & Mean (B) \\
\hline & \multicolumn{4}{|c|}{ 2018/2019 } & \multicolumn{4}{|c|}{$2019 / 2020$} \\
\hline & \multicolumn{8}{|c|}{ Circumference of the mother bulbs (cm) } \\
\hline Control & 8.25 & 7.55 & 7.55 & 7.78 & 5.65 & 7.80 & 6.25 & 6.57 \\
\hline Arginine (50 ppm) & 7.35 & 6.15 & 6.00 & 6.50 & 8.00 & 8.75 & 7.85 & 8.20 \\
\hline Arginine (75 ppm) & 7.07 & 5.65 & 7.35 & 6.69 & 7.90 & 8.00 & 7.75 & 7.88 \\
\hline Kristalon (2 g/l) & 5.95 & 6.55 & 6.90 & 6.47 & 6.90 & 8.25 & 8.45 & 7.87 \\
\hline Mean (A) & 7.15 & 6.47 & 6.95 & & 7.11 & 8.20 & 7.57 & \\
\hline \multirow[t]{2}{*}{ L.S.D $(0.05)$} & \multicolumn{4}{|c|}{$\mathrm{A}=\mathrm{N} . \mathrm{S} \mathrm{B}=\mathrm{N} . \mathrm{S} \mathrm{A} \times \mathrm{B}=\mathrm{N} . \mathrm{S}$} & \multicolumn{4}{|c|}{$\mathrm{A}=\mathrm{N} . \mathrm{S} \mathrm{B}=\mathrm{N} . \mathrm{S} \mathrm{A} \times \mathrm{B}=\mathrm{N} . \mathrm{S}$} \\
\hline & \multicolumn{8}{|c|}{ Fresh weight of the mother bulbs (cm) } \\
\hline Control & 5.15 & 5.70 & 5.80 & 5.55 & 3.29 & 5.13 & 3.72 & 4.05 \\
\hline Arginine (50 ppm) & 6.65 & 3.30 & 2.85 & 4.27 & 8.06 & 7.54 & 9.53 & 8.37 \\
\hline Arginine (75 ppm) & 2.85 & 2.75 & 4.35 & 3.31 & 5.67 & 6.43 & 4.44 & 5.52 \\
\hline Kristalon (2 g/l) & 2.65 & 3.70 & 3.35 & 3.90 & 4.46 & 8.02 & 6.57 & 6.35 \\
\hline Mean (A) & 4.32 & 3.86 & 4.58 & & 5.37 & 6.78 & 6.06 & \\
\hline \multirow[t]{2}{*}{ L.S.D $(0.05)$} & \multicolumn{4}{|c|}{$\mathrm{A}=\mathrm{N} . \mathrm{S} \mathrm{B}=\mathrm{N} . \mathrm{S} \mathrm{A} \times \mathrm{B}=\mathrm{N} . \mathrm{S}$} & \multicolumn{4}{|c|}{$\mathrm{A}=\mathrm{N} . \mathrm{S} \mathrm{B}=\mathrm{N} . \mathrm{S} \mathrm{A} \times \mathrm{B}=\mathrm{N} . \mathrm{S}$} \\
\hline & \multicolumn{8}{|c|}{ No. of bulblets/pot (bulblets yield) } \\
\hline Control & 4.50 & 3.50 & 2.50 & 3.50 & 2.50 & 2.00 & 2.50 & 2.33 \\
\hline Arginine (50 ppm) & 2.75 & 5.65 & 2.65 & 3.68 & 3.00 & 3.67 & 2.50 & 3.05 \\
\hline Arginine (75 ppm) & 3.40 & 4.50 & 3.75 & 3.88 & 2.92 & 3.25 & 2.00 & 2.72 \\
\hline Kristalon (2 g/l) & 4.00 & 4.45 & 3.75 & 4.07 & 3.50 & 3.50 & 2.10 & 3.03 \\
\hline Mean (A) & 3.66 & 4.52 & 3.16 & & 2.97 & 3.10 & 2.27 & \\
\hline \multirow[t]{2}{*}{ L.S.D $(0.05)$} & \multicolumn{4}{|c|}{$A=N . S B=N . S A \times B=N . S$} & \multicolumn{4}{|c|}{$A=N . S B=N . S A \times B=N . S$} \\
\hline & \multicolumn{8}{|c|}{ Fresh weight of bulblet (g) } \\
\hline Control & 6.70 & 7.80 & 6.70 & 7.07 & 5.95 & 8.60 & 6.90 & 7.15 \\
\hline Arginine (50 ppm) & 8.70 & 8.30 & 8.70 & 8.57 & 13.65 & 10.30 & 11.40 & 11.78 \\
\hline Arginine (75 ppm) & 8.05 & 6.00 & 8.05 & 7.36 & 8.95 & 10.85 & 8.95 & 9.58 \\
\hline Kristalon (2 g/l) & 9.20 & 8.25 & 9.20 & 8.88 & 13.95 & 9.85 & 14.90 & 12.90 \\
\hline Mean (A) & 8.16 & 7.58 & 8.16 & & 10.62 & 9.90 & 10.53 & \\
\hline L.S.D $(0.05)$ & \multicolumn{4}{|c|}{$\mathrm{A}=\mathrm{N} . \mathrm{S} \mathrm{B}=\mathrm{N} . \mathrm{S} \mathrm{A} \times \mathrm{B}=\mathrm{N} . \mathrm{S}$} & \multicolumn{4}{|c|}{$\mathrm{A}=\mathrm{N} . \mathrm{S} \mathrm{B}=\mathrm{N} . \mathrm{S} \mathrm{A} \times \mathrm{B}=\mathrm{N} . \mathrm{S}$} \\
\hline
\end{tabular}

L.S.D $(0.05)=$ Least significant differences at 0.05 level of probability.

the new formed bulbs in both seasons. Meanwhile, arginine at $75 \mathrm{ppm}$ also raised potassium $\%$ in the new bulbs. The interaction on the other side, proved the great influence of using sand + compost medium in plantation with treating plants with kristalon in giving the highest value in both seasons.

\section{REFERENCES}

Agina, Effat A.M.; Shalaby, H.S.; ElKhayal, A.S. and Kaorkar, M.H. (2005).
Effect of foliar fertilization and some growth regulators on growth and chemical composition of some ornamental plants. Proc. $6^{\text {th }}$ Arab Conf. Hort., March $20-22^{\text {nd }}$, Hort. Dept., Fac. Agric., Ismailia, Egypt, pp. 101.

Amarjects, S.; Godara, N.R. and Singh, A. (1995). Studies on the nutritional requirements of tuberose cv. Single during growth. Haryana Agric. Univ. J. Res., 25(4):171-174. 
Table 4. Effect of different growing media, fertilization treatments and their interaction on chemical constituents of Iris tingitana cv. Golden Beauty in the two seasons of $2018 / 2019$ and $2019 / 2020$.

\begin{tabular}{|c|c|c|c|c|c|c|c|c|}
\hline \multirow{3}{*}{ Treatments (B) } & \multicolumn{8}{|c|}{ Growing media (A) } \\
\hline & Sand & $\begin{array}{c}\text { Sand + } \\
\text { clay }\end{array}$ & $\begin{array}{c}\text { Sand }+ \\
\text { compost }\end{array}$ & Mean (B) & Sand & $\begin{array}{c}\text { Sand + } \\
\text { clay }\end{array}$ & $\begin{array}{c}\text { Sand }+ \\
\text { compost }\end{array}$ & Mean (B) \\
\hline & \multicolumn{4}{|c|}{ 2018/2019 } & \multicolumn{4}{|c|}{$2019 / 2020$} \\
\hline & \multicolumn{8}{|c|}{ Total carbohydrates \% in bulbs } \\
\hline Control & 37.02 & 40.47 & 35.45 & 37.65 & 39.13 & 42.59 & 37.32 & 39.68 \\
\hline Arginine (50 ppm) & 40.82 & 41.05 & 45.71 & 42.53 & 42.52 & 43.32 & 47.23 & 44.36 \\
\hline Arginine (75 ppm) & 40.26 & 47.54 & 46.11 & 44.64 & 42.38 & 49.38 & 48.42 & 46.73 \\
\hline Kristalon (2 g/l) & 49.80 & 47.30 & 38.35 & 45.15 & 51.25 & 49.12 & 40.50 & 46.96 \\
\hline \multirow[t]{2}{*}{ Mean (A) } & 41.98 & 44.09 & 41.41 & & 43.82 & 46.10 & 43.37 & \\
\hline & \multicolumn{8}{|c|}{ Nitrogen $\%$ in new formed bulbs } \\
\hline Control & 1.907 & 1.503 & 2.345 & 1.918 & 2.512 & 2.132 & 2.913 & 2.519 \\
\hline Arginine (50 ppm) & 2.077 & 2.084 & 3.237 & 2.466 & 2.645 & 2.622 & 3.823 & 3.030 \\
\hline Arginine (75 ppm) & 2.692 & 3.066 & 3.111 & 2.956 & 3.232 & 3.615 & 3.752 & 3.533 \\
\hline Kristalon (2 g/l) & 2.209 & 1.720 & 2.638 & 2.189 & 2.752 & 2.345 & 3.135 & 2.744 \\
\hline \multirow[t]{2}{*}{ Mean (A) } & 2.221 & 2.093 & 2.833 & & 2.785 & 2.678 & 3.406 & \\
\hline & \multicolumn{8}{|c|}{ Phosphorus \% in the new formed bulbs } \\
\hline Control & 0.368 & 0.406 & 0.456 & 0.410 & 0.462 & 0.515 & 0.549 & 0.509 \\
\hline Arginine (50 ppm) & 0.411 & 0.580 & 0.467 & 0.486 & 0.521 & 0.632 & 0.587 & 0.580 \\
\hline Arginine (75 ppm) & 0.438 & 0.600 & 0.537 & 0.525 & 0.545 & 0.711 & 0.625 & 0.627 \\
\hline Kristalon (2 g/l) & 0.505 & 0.833 & 0.629 & 0.655 & 0.622 & 0.905 & 0.742 & 0.756 \\
\hline \multirow[t]{2}{*}{ Mean (A) } & 0.431 & 0.605 & 0.522 & & 0.538 & 0.691 & 0.626 & \\
\hline & \multicolumn{8}{|c|}{ Potassium \% in the new formed bulbs } \\
\hline Control & 1.628 & 1.171 & 1.724 & 1.508 & 1.922 & 1.498 & 2.143 & 1.854 \\
\hline Arginine (50 ppm) & 1.688 & 1.640 & 1.865 & 1.731 & 2.052 & 1.952 & 2.209 & 2.071 \\
\hline Arginine (75 ppm) & 1.725 & 1.654 & 2.056 & 1.812 & 2.150 & 1.980 & 2.512 & 2.214 \\
\hline Kristalon (2 g/l) & 2.029 & 1.737 & 2.243 & 2.003 & 2.415 & 2.186 & 2.681 & 2.427 \\
\hline Mean (A) & 1.768 & 1.551 & 1.972 & & 2.135 & 1.904 & 2.386 & \\
\hline
\end{tabular}

L.S.D $(0.05)=$ Least significant differences at 0.05 level of probability.

Arafa, N.M.; Nabih, A. and Ibrahim, G.A. (1996). Freesia refracta cv. Aurora production and quality as influenced by some factors, corms and cormlets yield and quality produced from plants raised in different growing media treated with different types of chemical fertilization. Egypt. J. Appl. Sci., 11(10):139-161.

Askar, F.A. (1988). Stability of soil conditioners for desert and cultivated soil in Egypt. Inter. Symp. Soil Conditioners, Egypt. pp. 133-142.

Auda, M.S. (1992). Physiological Studies on Amaryllis Bulbs. Ph.D. Thesis., Fac. Agric., Ain Shams Univ., Egypt, 193 p.
Black, C.A. (1965). Methods of Soil Analysis, Part I and II. Amer. Soc. Agron., Madison, Wise, U.S.A, 770 p.

De Hertogh, A.A. and Le Nard, M. (1993). The Physiology of Flower Bulbs. ElSevier Sci. Publ., B.V., The Netherland, $811 \mathrm{p}$.

Dewis, J. and Freitas, F. (1970). Physical and chemical methods of soil and water analysis. Food and Agric. Organization of the United Nations, $275 \mathrm{p}$.

El-Ashry, A.I.; Auda, M.S. and Bakry, M.Y. (1995). Response of amaryllis (Hippeastrum vittatum Herb) to different 
growing media and chemical fertilization levels. Journal Agric. Res., Tanta Univ., 21(4):754-761.

El-Bably, S.M. (1998). Physiological Studies on Tuberose and Pancratium Bulbs. M.Sc. Thesis, Fac. Agric., Kafr ElSheikh, Tanta Univ., Egypt, 168 p.

El-Hanafy, S.H.; Nabih, A. and Badawy, O.E.F. (2005). Effect of shading and chemical fertilization on growth, flowering and corm productivity of Freesia refracta cv. Aurora. Proc. $3^{\text {rd }}$ Conference on Recent Technology in Agric., Cairo, Univ., pp. 571-593

Emam, K.A.; Gomaa, S.A. and Khela, Evon A. (2017). Effect of foliar spraying with some amino acids and fertilizer levels on growing of moringa seedlings. J. Biol. Chem. Environ. Sci., 12(1):239-261.

Floyed, G.A. (1965). Raising and Planting Out of Blackout in Jiffy Pots for Corms. Tech., 9 p.

Hall, N.J. and Richmound, K.P. (1968). Raising Eucalypts in pots. Aust. For., 23:46-48.

Hoog, M.H. (1980). Bulbous Irises. The Plantsman, 2:141-164.

John, M.K. (1970). Colorimetric determination of phosphorus in soil and plant materials with ascorbic acid. Soil. Sci., 109(4):214-220.

John, S.H. and David, A.W. (2000). Soil conditions. North Central Regional Extension Publications, 295.

Khalafalla, M.; El-Mahrouk, E.; Nofal, E.; Nabih, A. and Goma, S.A. (2000). Physiological Studies on Ornithogalum thrysoides, Jack. J. Agric. Res., Tanta Univ., 26(2):262-277.

Mahdy, H.M. (1995). Physiological Studies on Iris tingitana L. M.Sc. Thesis, Fac. Agric., Seuz Canal Univ., Egypt, 95 p.

Mansour, H.A.; Hussein, M.M.M.; Gomaa, S.A. and El-Ghazaly, N.F.A. (2015). Response of Gladiolus grandiflorns cv.
Peter Pears to different drip irrigation levels and kristalon treatments. J. Biol. Chem. Environ. Sci., 10(2):417-433.

Nabih, A. (1991). Effect of some potting media and chemical fertilization on growth, flowering and corm productivity of Freesia refracta cv. Aurora. J. Agric. Res., Tanta Univ., 17(3):713-733.

Nabih, A.; El-Sayed, A.A. and Aly, A.A. (1987). Effect of different soil media and fertilizer treatments on growth, flowering and bulb formation of iris bulbs cv. Golden Beauty. J. Agric. Res., Tanta Univ., 13(4):1053-1065.

Rai, V.K. (2002). Role of amino acids in plant responses to stress. Biological Plantarum, 45(4):481-487.

Sadak, M.S.; Abd El-Hamid, M.T. and Schmidhalter, U. (2015). Effect of foliar applications of amino acids on plant yield and some physiological parameters in bean plants irrigated with seawater. Acta Boil. Colomb., 20(1):141-152.

SAS program (1994). SASISTAT User's Guide; Statistics g Vers. 6.04, $4^{\text {th }}$ Ed. SAS Institute Inc., Cary. N.C., U.S.A.

Shehata, S.M.; Heba, S.A.A.; Abou ElYazid, A. and El- Gizawy, A.M. (2011). Effect of foliar spraying with amino acids and seaweed extract on growth, chemical constituents, yield and its quality of celeriac plant. European Journal of Scientific Research, 58(2):257-265.

Singh, K.P. (1996). Studies on size of cormlets and levels of $\mathrm{N}$ on corm multiplication in gladiolus cv. Pink Friendship. Advances in Plant Sci., 9(2):241-243.

Smith, E.; Gilles, M.A.; Hamiton, D.K. and Gedees, P.A. (1956). Colorimetric method for determination of sugars and related substances. Ann. Chem., 28(1):350.

Snedecor, W.G. and Cochran, G.W. (1980). Statistical Methods, $7^{\text {th }}$ Ed. Iowa State Univ. Press, Ames, Iowa, USA., 507 p. 
Soliman. M.A. (2002). Physiological and Anatomical Studies on Some Ornamental Bulbs. Ph.D. Thesis, Fac. Agric., Kafer El-Sheikh, Tanta Univ., Egypt, 136 p.

\section{تأثثير بيئات النمو و أنماط من التسميد والتفاعل بينهما على النمو والإزهار و إنتاجية الأبصال وبعض التصات

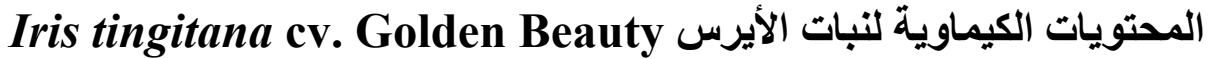

$$
\text { قسم بحوث الحدائق النباتية، معهد بحوث درثام البساتين، مركز الغني خضوث الزر اعية، الجيزة، مصر }
$$

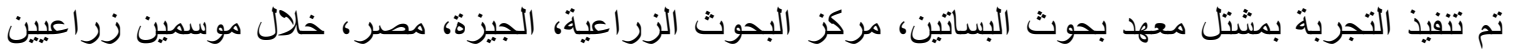

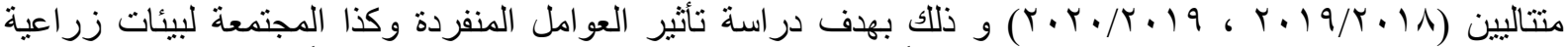

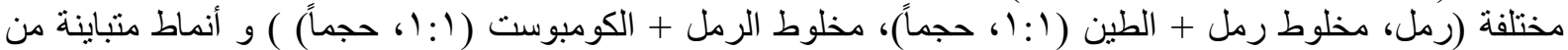

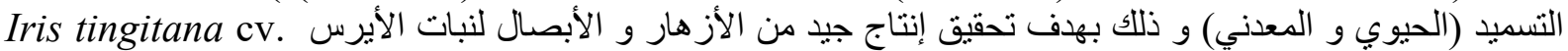
Golden Beauty

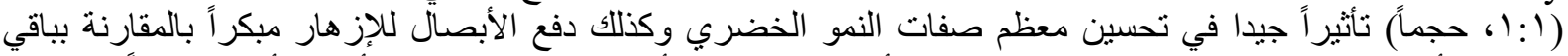

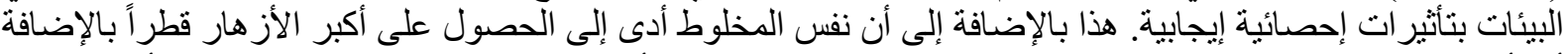

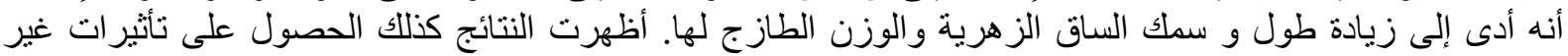

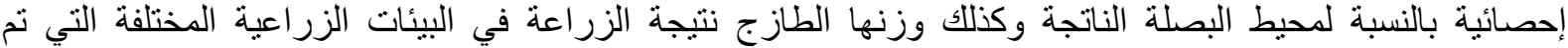

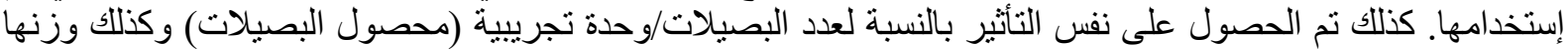

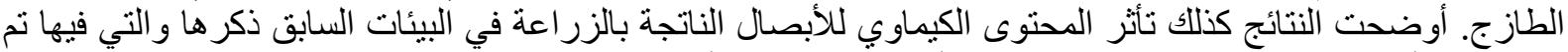

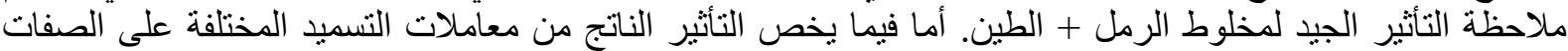

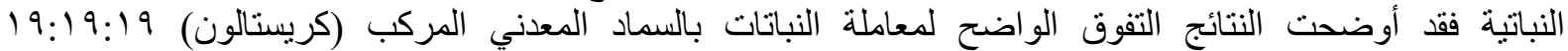

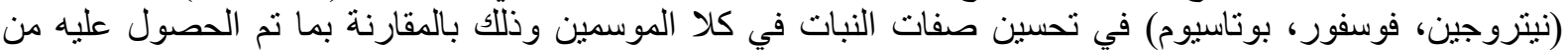

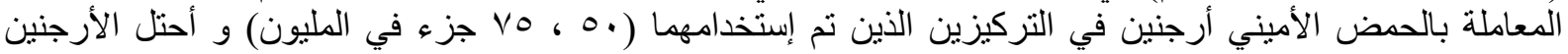

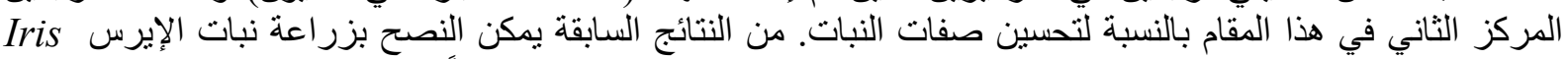
(tingitana cv. Golden Beauty

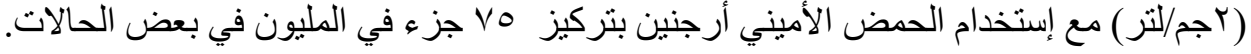

